\title{
What Influences Principals' Perceptions of Academic Climate? A Nationally Representative Study of the Direct Effects of Perception on Climate
}

\author{
Angela Urick \\ The University of Oklahoma \\ Urick@ou.edu
}

\author{
Alex J. Bowers \\ Teachers College, Columbia University \\ Bowers@tc.edu
}

\begin{abstract}
: 12
Using a nationally representative sample of public high schools $(n=439)$, we examined the extent to which the principal's perception of their influence over instruction, the evaluation of non-academic related tasks as well as academic related tasks, and their relationship with the school board and central office relates to how they view teachers and students in the classroom through academic climate while controlling for school level covariates. Little attention has been given to date to the principal's perception of their responsibilities and how it relates to their view of the school and overall academic climate. The findings of this study link principal academic climate with direct effects from principal perceptions of support from the central office and the evaluation of their position.
\end{abstract}

Keywords: Academic climate, school climate, organizational climate, instructional leadership, principals, leadership, school administration, regression, high school

\section{INTRODUCTION}

Historically, a broad domain of research literature has focused on examining the links between principal evaluations, behaviors and increased school performance (Murphy, Elliott, Goldring \& Porter, 2007). However, to date little is known about the principal's perception of their position and how it relates to successful school conditions. A long history of school leadership literature has found particular processes of the principal to be related to student outcomes through mediating the working environment of teachers and students through the academic climate of the school (Hallinger \& Heck, 1996; Heck \& Marcoulides, 1996; Murphy, Elliott, Goldring \& Porter, 2007; Leithwood \& Mascall, 2008; Seashore Louis, Leithwood, Wahlstrom, Anderson, Michlin, Mascall, Gordon, Strauss, Thomas \& Moore, 2010; Tarter, Sabo \& Hoy, 1995). This line of research theorizes that through the development of academic climate, principals are able to influence student learning. These positive environments centered on learning have been shown to possibly reduce the impact of inalterable social factors on student learning within the school, which increases the ability of schools

\footnotetext{
${ }^{1}$ This document is a pre-print of this manuscript, published in the journal Leadership and Policy in Schools. Recommended Citation: Urick, A., \& Bowers, A. J. (2011). What Influences Principals' Perceptions of Academic Climate? A Nationally Represenative Study of the Direct Effects of Perception on Climate. Leadership and Policy in Schools, 10(3), 322-348. doi: 10.1080/15700763.2011.577925

${ }^{2}$ At time of publication, both co-authors were at the University of Texas at San Antonio

Note: This document was last updated on Dec 11, 2014

Urick \& Bowers (2011)
}

to make substantive differences in student outcomes (Anderson, 1982; Goddard, Sweetland, \& Hoy, 2000; Griffith, 1999; Heck, 2006; Hoy \& Hannum, 1997; Hoy, Tarter, \& Bliss, 1990; Hoy, Tarter \& Woolfolk Hoy, 2006; Phillips, 1997; Rice, 2001; Shouse, 1996; Wilkins \& Kuperminc, 2010). In addition, positive academic climates have been shown to be characteristic of high performing schools at all grade levels (MacNeill, Prater \& Busch, 2009; Seashore Louis, Leithwood, Wahlstrom, Anderson, Michlin, Mascall, Gordon, Strauss, Thomas \& Moore, 2010). In the current study, we take the school's academic climate as our primary focus, and postulate that perhaps particular aspects of a principal's position either positively or negatively influence their view of academic climate within their schools. This view of the academic climate though the principal is important to consider since a principal's perceived ability to lead the school is highly associated with school and classroom conditions, and in turn, overall student achievement and individual student growth in achievement (Heck \& Hallinger, 2009; Leithwood \& Jantzi, 2008). Knowing which factors of principal influence, assessment and relationships increase a positive view of academic climate may provide school leaders, district administrators and policy makers with further evidence to show how to support principals in leading successful schools through the development of stronger academic climates.

This study is guided by the following research question: to what extent do factors of a principal's perception of their own influence, evaluation and relationships impact their view of the academic climate? We used stepwise multiple linear regression to investigate the unique contribution of school characteristics and the principal leadership position on academic climate. We found that factors related to the evaluation of the principal that were influenced by academic performance and implementation of reforms lead to a significant increase in the principals' perception of the school's academic climate. In addition, a perceived cooperative relationship with district officials positively and significantly influenced their view of the academic climate. However, the degree of social disorder, or behavior issues, and the evaluation of principals on a disciplinary environment was negatively associated with their perception of the overall academic climate. The next section reviews the literature related to the importance of academic climate, principal leadership and principal perceptions. A description of the methods is given in a subsequent section, followed by detailed results and a discussion of links to literature, implications and suggestions for future study.

\section{REVIEW OF LITERATURE}

A principal's leadership of instruction, managerial style, decisions and negotiation of external and internal pressures has shown both direct and indirect relationships with student learning (Heck, 2000; Heck, Larsen \& Marcoulides, 1990; Hoy \& 
Hannum, 1997; Robinson, Lloyd \& Rowe, 2008; Supovitz, Sirinides \& May, 2009). Although direct relationships with student achievement have been weak and not well established, the principal's leadership has consistently been associated with the establishment of teachers' expectations and goals for students within the classroom. Known as academic climate, researchers have argued that it is these shared perceptions of behavior around instruction, leadership and the morale of the teachers and students that mediates the influence of the principal on student achievement (Goddard, Sweetland, \& Hoy, 2000; Griffith, 1999; Heck, 2006; Heck \& Marcoulides 1996; Hoy \& Hannum, 1997; Hoy, Tarter, \& Bliss, 1990; Hoy, Tarter \& Woolfolk Hoy, 2006; MacNeil, Prater \& Busch 2009; Phillips, 1997; Rice, 2001; Shouse, 1996).

However, fewer studies have focused on the factors associated with the principal's perceptions of academic climate (Leithwood \& Janzti, 2008). Described as "self-efficacy", Leithwood and Jantzi (2008) demonstrated that not only did the leader's perception of the climate of the school mediate student achievement, but that specific "antecedent" factors were associated with a principal's perception of the school climate. Combining the literature as well as their findings, Leithwood and Jantzi (2008) noted that while principal background and demographic factors, such as gender and ethnicity, were not significantly related to self-efficacy, organizational characteristics, such as school size and school level, were significantly related to self-efficacy in their model. These findings demonstrate the importance of school characteristics on the principal's view of their own leadership ability, which further suggests the importance of other school factors and aspects of a principal's position on how they view the success of their leadership. Thus, the school context and school condition under which principals operate possibly have more influence on their perceptions than their own experience and background.

Yet, while Leithwood and Jantzi (2008) note in their literature review a need to study the factors associated with the principal's perception of the academic climate, their study focused primarily on organizational effects. Currently left unaddressed in the literature is the principal's own perception of the academic climate, which is the focus of the present study.

\section{Academic climate}

Academic climate has been shown to be a significant factor associated with the difference between higher and lower performing schools (MacNeil, Prater \& Busch, 2009). In addition, the focus on perceptions of academic climate better represents the learning environment present in low SES schools compared to only using measures of student achievement (Battistich, Solomon, Kim, Watson, \& Schaps, 1995; Mortimore, 1993). Although, these measures of the academic climate have been related to traditional measures of student achievement and outcomes (Anderson, 1982; Goddard, Sweetland, \& Hoy, 2000; Griffith, 1999; Heck, 2006; Hoy \& Hannum, 1997; Hoy, Tarter, \& Bliss, 1990; Hoy, Tarter \& Woolfolk Hoy, 2006; Phillips, 1997; Rice, 2001; Shouse, 1996; Wilkins \& Kuperminc, 2010), they also have been a measure found to counteract the effects of socioeconomic status on test scores (Heck, 2006; Hoy, Tarter, Woolfolk Hoy, 2006). Academic climate has been defined as the perceptions of behaviors in which academic achievement is highly valued and teachers and students are motivated to focus on learning (MacNeil et al., 2009). Heck (2006) found that when student achievement growth was examined, student background and context effects were minimized and the difference between schools was instead explained by processes of academic climate, which highlights the practical usefulness of academic climate and emphasis on equity in schools. Furthermore, Anderson (1982) argued that these processes of academic climate, a combination of climate and organizational structure, together mediate student outcomes. Several factors have consistently and specifically been ascribed to academic climate, including academic expectations, student and teacher morale, and student motivation toward work. Nevertheless, other aspects of the organization, such as a leader's role in the school structure and direction, have recently been examined in relation to perceptions of academic climate.

Perceptions of academic climate have to date been defined in three main ways, by measures of academic expectations, morale, and an emphasis on students completing homework. First, academic expectations have been referred to as academic press or emphasis (Goddard, Sweetland \& Hoy, 2000; Hoy, Sweetland \& Smith, 2002; Hoy, Tarter \& Bliss, 1990; Hoy, Tarter \& Woolfolk Hoy, 2006). For example, these conceptualizations have included items which inquire to what extent teachers and/or students perceive that students work hard and respect others who achieve, students can achieve the goals that have been set for them, and teachers set high and achievable goals (Goddard, Sweetland \& Hoy, 2000; Hoy, Sweetland \& Smith, 2002; Hoy, Tarter \& Bliss, 1990; Hoy, Tarter \& Woolfolk Hoy, 2006). These items have been utilized as a construct of organizational health, a predictor of collective efficacy and factors directly related to student achievement. In addition, these academic expectations have been shown to possibly reduce achievement gaps (McKown \& Weinstein, 2008) and counteract negative behavior (McEvoy \& Welker, 2000).

Second, relationships between teachers and students, teachers and teachers and between students and peers have been defined as the morale within the school, or the motivation toward a focus on learning environment behaviors alongside academic expectations. For example, with the teacher as the unit of analysis, Hoy, Tarter and Bliss (1990) described morale as whether or not teachers in the school liked each other. In addition, as a measure of a healthy climate, Hoy and Hannum (1997) described morale as teacher affiliation, which emphasized a teacher's commitment to encourage students and to develop collegial relationships with teachers. With the student as the unit of analysis, Danielsen, Wiium, Wilhelmsen \& Wold (2010) surveyed students about their perceptions of their relationships with teachers and students as being friendly, helpful and inclusive. These positive relationships, or morale, have been found to directly influence student outcomes (Brand, Felner, Shim, Seitsinger \& Dumas, 2003; Comer, 1980; Corwin \& Borman, 1988; Danielsen et al., 2010; Hoy \& Hannum, 1997).

Third, a more specific measure of academic climate has been the perceived importance of homework, which has been used as a description of academic expectations and morale (Phillips, 1997; Shouse, 1995). Oaks (1989) grouped the quality and type of homework with other measures of academic press, which corresponded to student and teacher access to knowledge as constructs of overall classroom teaching and learning. Griffith (1995) utilized items about homework to measure both the academic press in the classroom and to determine morale regarding homework. As an item of morale or academic press in academic climate, homework has helped to explain student academic outcomes (Griffith, 1995). Moreover, outside of the 
context of academic climate, the number of hours students spent on homework is significantly related to academic achievement (Rumberger \& Palardy, 2005).

\section{Principal's relationship to academic climate}

The principal has been found to establish an academic climate within their school (Firestone \& Wilson, 1985; Heck, 2000; Leithwood \& Jantzi, 1999; Leithwood, Mascall, Strauss, Sacks, Memon \& Yashkina, 2007; Printy, 2008; Raudenbush, Rowan \& Kang, 1991; Tschannen-Moran, 2009). The principal creates academic climate through vision, mission, goals, purposes, leadership tasks, instructional support, and a coinciding safe environment (Firestone \& Wilson, 1985; Heck, 2000; Leithwood \& Jantzi, 1999; Leithwood, et al., 2007; Printy, 2008). In fact, Raudenbush, Rowan \& Kang (1991) found that teacher control over the classroom and teacher morale, both measures of academic climate, were predicted by school level variables, and principal leadership accounted for the most variance in school climate within and between schools. In addition, Leithwood and Jantzi (1999) concluded that the principal leadership effects were greater than teacher leader effects when mediated through student engagement. Thus, the principal is an important unit of analysis when attempting to examine academic climate.

The study of principal leadership in the context of climate is important because it is through academic climate that a principal can impact student outcomes. Seashore Louis, Leithwood and associates (2010) in a report of research on leadership and learning discussed this as, "as Harris (2002) points out, secondary school principals seem to influence teachers and teaching practice because of the organizational climate they create, not through specific interactions or interventions" (p. 45). These mediated models of principal effects have shown that principals influence student outcomes through academic climate (Hallinger \& Heck, 1996; Heck \& Marcoulides, 1996; Murphy, Elliott, Goldring \& Porter, 2007; Leithwood \& Mascall, 2008; Seashore Louis, Leithwood, Wahlstrom, Anderson, Michlin, Mascall, Gordon, Strauss, Thomas \& Moore, 2010; Tarter, Sabo \& Hoy, 1995). These effects are enacted through leadership tasks or processes which are then mediated through teacher perceptions of the academic climate to school performance, individual student achievement, as well as other measures of student success (Hallinger \& Heck, 1996; Heck and Marcoulides, 1996; Murphy, et al., 2007; Leithwood \& Mascall, 2008; Tarter, Sabo \& Hoy, 1995). In a review of the principal's role in school effectiveness spanning over a decade of study, Hallinger and Heck (1996) concluded that the most theoretically and empirically robust models utilized internal processes, such as academic expectations, to link principals to the practice of teachers, which frequently uncovered a significant indirect relationship between principal effects and student achievement. In addition, Seashore Louis, Leithwood, and associates (2010) presented key findings about the principal's creation of, what they termed, an instructional climate, setting a tone and vision for student achievement and teacher growth. They reported that teachers in secondary schools perceived less of an instructional climate emanating from principal leadership than elementary school teachers. However, this instructional climate was found to be present in highperforming schools of all grade levels, K-12 (Seashore Louis, et al., 2010). These findings are important as they relate to the mediators of academic climate in two main ways. First, these findings suggest that principal leadership in relation to the academic climate is a means for principals to support and positively influence student outcomes. Second, given the findings of Seashore Louis et al. (2010), the study of secondary school principals may be of particular interest since elementary school teachers seemed to already view their principals as creating more of an academic climate. More study is needed to better understand the academic climate with the principal as the unit of analysis in secondary schools.

\section{School context and academic climate}

Much of the research to date suggests that school level context and characteristics are related to school performance, leadership and academic climate. Many of these context effects have been defined as school size, grade level, urbanicity, and socioeconomic status, and multiple studies have shown that these school contexts are associated with academic climate (Garmezy, 1991; Gottredson, Gottredson, Payne \& Gottredson, 2005; Raudenbush, Rowan \& Kang, 1991; Seashore Louis et al., 2010; Welsh, 2000; Wilson, 2004). Increasing poverty and school size corresponds with more negative perceptions of the school context, while teachers in urban schools and secondary schools have viewed leadership as more negative compared to teachers in elementary and rural schools (Seashore Louis et al., 2010). These factors have helped to identify the type of schools for which the impact of leadership has differed.

In addition, the degree of social disorder, for example misconduct, physical fights, theft, have impacted views of the academic climate. An unsafe environment with discipline problems does not allow for students, teachers and principals to focus on learning and creates negative perceptions of students. Edmonds (1979) and the other early 1980's school effectiveness researchers note that discipline is one of the core aspects of leadership for effective schools. However, further research in this domain has indicated that discipline and issues around social disorder in a school influence the academic climate in the following three additional ways. First, a more positive school academic climate is associated with fewer incidences of student misconduct, disruptive behaviors and aggression (Gottfredson, Gottfredson, Payne \& Gottfredson, 2005; Meece, 2006; Welsh, 2000; Wilson, 2004). Second, a safe and orderly environment contributes to the academic climate of the school when good discipline is combined with academic expectations and morale (Brand, Felner, Shim, Seitsinger \& Dumas, 2003; Goh, Young \& Fraser, 1995; Griffith, 1999; Griffith, 1995; Rumberger \& Palardy, 2005). Third, the creation of an orderly and supportive environment is a leadership dimension that links to student outcomes (Griffith, 1999; Robinson, Lloyd \& Row, 2008). Not only does academic climate support improved academic achievement, but a simultaneous reinforcement of a safe and orderly environment helps to decrease behavior problems within the school and works to further increase individual student academic motivation through an increased academic climate (Brand, Felner, Seitsinger, Burns \& Bolton, 2008; Danielsen, Wiium, Wilhelmsen \& Wold, 2010; Goh, Young \& Fraser, 1995; Rizzuto, LeDoux \& Hatala, 2009). Much of this past literature has also shown that attention to a positive academic climate and low levels of discipline issues can positively influence academic achievement, especially for students from disadvantaged backgrounds (Gottfredson, Gottfredson, Payne \& Gottfredson, 2005; McEvoy \& Welker, 2000). McEvoy and Welker (2000) posit that student misbehavior can be managed through the achievement expectations and morale accompanied by discipline through school leadership. This establishment of a positive academic climate and attention to student discipline counteracts negative student behavior or social disorder within the school and 
classroom (Gottfredson, Gottfredson, Payne \& Gottfredson, 2005; Meece, Anderman \& Anderman, 2006; Welsh, 2000; Wilson, 2004), which allows for a focus on and increase in achievement for students with the greatest need for improvement. For example, Robinson, Lloyd and Rowe (2008) in a meta-analysis of leadership types found 42 effect sizes measuring one of five leadership dimensions, a principal's ability to establish an orderly school without interruptions, which produced a mean effect size of .27 on student outcomes. However, missing from much of the literature around the relationship between climate and discipline has been a discussion of the independent effects of the degree of social disorder and discipline related leadership tasks on the principal's perception of academic climate. Indeed, little is known about whether the negative effects of discipline and social disorder issues on academic climate from the view of the school leader are independent of other school-level variables, such as low SES, school size, urbanicity and the like. This is an important point since Goldring, Huff, May and Camburn (2007) have shown that it is the school context conditions, rather than principal background and experience, which predicts what type of leadership qualities a principal may exhibit in a school. Hence, currently there is a need to examine issues around discipline and social disorder as they relate to the principal's perception of the academic climate.

To date, the relationship between attention to discipline and academic climate has not been explored as an independent effect on academic climate from the principal's perspective, with a sole focus on the school leader who is responsible for directing the disciplinary and academic climate. Rather, the majority of the focus has been teacher and student perceptions of the degree of good discipline within the school as a measure of the overall climate related to student outcomes.

Principal leadership variables related to academic climate Several leadership processes have been found to predict the academic climate in schools. The majority of principal leadership variables found to significantly predict school quality deal with the degree of influence principals have on instruction (Goldring, Porter, Murphy, Elliott \& Cravens, 2009; Heck, 2006; Heck, Larsen \& Marcoulides, 1990; Supovitz, Sirinides \& May, 2010). In addition, this instructional influence has been combined with the principal's ability to establish relationships with the community (Goldring et al. , 2009; Heck, 2006; Heck, Larsen \& Marcoulides, 1990). In fact, a principal's relationship with external communities has been an additional key process from which principals are evaluated (Goldring et al., 2009). In a review of literature by Robinson, Lloyd and Rowe (2008), principal dimensions other than academic climate found to influence student outcomes were the planning, coordinating and evaluating of curriculum and promoting of teacher learning, which produced the largest consistent effect sizes. In addition, the creation of an orderly and supportive environment, a dimension more related to managerial and discipline tasks, was also consistently significantly associated with increased student outcomes (Robinson et al., 2008). Outside if the principal's leadership, district leaders have also provided evaluations and expectations of principals that can change the academic climate (Firestone \& Martinez, 2007). This district support and evaluation of schools has included the distribution of materials, monitoring of improvement and development of people (Bowers, 2008; Firestone \& Martinez, 2007). Firestone and Martinez (2007) argued that the district, through their conditions, has more support on school instruction than research has regularly indicated. The conditions placed on the principal from the district would control their influence of instruction and improvements to the academic climate. In addition to district evaluation and support, the school context as discussed above, plays an important role in defining how a principal leads a school. Goldring, Huff, May \& Camburn (2007) found that the leadership characteristics of a principal were best predicted by the percent of disadvantaged students and teachers' perceptions of academic press. This organizational context explained how principals set academic goals, related to community, influenced instruction and managed non-academic related tasks, such as discipline. These findings further address the importance of academic climate, but also switch the focus of background variables from the principal to the school.

Overall, principal influence on instruction, relationships with community, managerial and disciplinary tasks have been found to influence the academic climate. District evaluation or monitoring of these responsibilities and the relationship between school and district has also been found to predict these instructional practices of the school, and in turn, academic climate. Further, Goldring and associates (2007) found that characteristics of the school context influence principal leadership rather than the background of their experience and training. However, to date, no study has examined the principal's perception of these tasks on their view of the academic climate.

\section{Importance of principal's perception}

Due to the direct relationship between principal leadership and academic climate, the principal's perception of the academic climate provides a unique measure of academic climate, which has received little attention in the literature. Principal perception of academic climate gauges the principal's view of the extent to which they have created a successful academic climate. This concept is similar to self-efficacy. Since little to no research has been conducted solely on the principal's perception of academic climate, the current study extends the literature on principal selfefficacy. Leithwood and Jantzi (2008) studied principal self and collective efficacy, since principal's beliefs had been under studied. According to Leithwood and Jantzi (2008) "we know very little about the efficacy beliefs of leaders in particular and even less about the antecedents of those beliefs"( p. 497). These authors investigated the contribution of self-efficacy and collective efficacy to the process of leadership that links to student achievement. They found that district leadership in academic press and vision influenced principal collective efficacy through these district conditions. The beliefs of the principals then indirectly influenced student achievement through school conditions. Thier study demonstrated the importance of principal beliefs toward successful leadership, but also the contribution of district conditions to those beliefs.

In sum, the context of the school, socioeconomic status, school size, school level, and urbanicity are known to be associated not only with the academic climate, but also with the type of leadership the principal provides the school. Principal influence over instruction, and management of non-academic related tasks and discipline have been found to impact academic climate which in turn is associated with student achievement. However, the principal's relationship with the district office as well as the amount of emphasis the district places on academic standards additionally influences the school's academic climate and processes around instruction. Therefore, the principal's perception of their own position, including district evaluation of this position, may be related to the principal's perception of 
academic climate. The principal's perception of academic climate provides a measure of the degree to which they have influenced the academic climate of the school. This unique perception of academic climate and its antecedent factors are necessary to better understand the process of how principals begin to change the academic climate of a school.

Therefore, the research question at the center of this study is to ask to what extent are school demographic and the principal's perception about their instructional influence, their management and the performance of the school, and their relationship with the district associated with the principal's perception of school climate? This study uses a nationally representative sample of principals from the Educational Longitudinal Study of 2002 (ELS:2002) to investigate the leadership and school factors that contribute to public, high school principal's perception of academic climate. We used a forward stepwise multiple regression to systematically examine the independent effects of the principal's perception of academic climate.

\section{METHODS}

This study is a cross-sectional, secondary analysis of the public access Education Longitudinal Survey of 2002 (ELS:2002) base year administrator questionnaire. Collected by the National Center for Education Statistics (NCES), ELS:2002 is a nationally representative sample of about 750 public and private high schools from across the United States in 2002 (Ingles et al. 2004; Ingles et al. 2007). For the 2002 base year of this NCES study, school administrators were surveyed in order to gather information on schools in the following six areas: school characteristics, student characteristics, teaching staff characteristics, school policies and programs, technology and school governance and climate (Ingles et al. 2004; Ingles et al. 2007). In the current study we utilized school characteristics, governance and policies to model school academic climate.

\section{Sample}

In the present study, we analyzed a subset of the ELS:2002 dataset, namely public schools with complete data. ELS:2002 contained partial data on 586 public schools. However, missing data was an issue, with variables with non-overlapping missing data from the administrator survey and reported school characteristics. With the missing data from the background variables of enrollment, urbanicity, and grade 10 percent free and reduced price lunch, the listwise deletion resulted in $n=407$, however our final sub-sample used in this study was $n=439$ public schools. Multiple imputation was used to impute missing data for the $n=439$ sample across the administrator survey question variables. Across the principal perception variables discussed below, there was less than $9 \%$ missingness. According to the missing data theory literature (Enders, 2008), multiple imputation is recommended.

In Table 1, we provide the means, standard deviations, minimum, maximum and original ELS:2002 variable codes for each of the variables included in the model.

\section{Academic Climate}

The ELS:2002 dataset provides a unique opportunity to examine the school-level influence of school policies and governance on the academic climate using a large national sample. Using previous literature on school academic climate (Goddard, Sweetland \& Hoy, 2000; Griffith, 1995; Heck, 2006; Hoy, Tarter, Bliss, 1990; Hoy, Tarter, Woolfolk Hoy, 2006; Phillips, 1997;
Wilkins \& Kuperminc, 2010) the dependent variable of academic climate was constructed in the following way. Academic climate was measured by the school administrator responses about the academic climate of teachers and students (see Table 2). Administrators were asked to indicate to what extent each of the 5 listed characteristics described their school climate: Student morale is high, Teachers at this school press students to achieve academically, Teacher morale is high, Students place a high priority on learning, Students are expected to do homework. The scale of responses ranged from "not at all accurate" $(0)$ to "very accurate" (4).

\section{Principal's leadership}

The independent variables related to leadership were selected from the ELS:2002 administrator questionnaire of school policies and governance based on past literature indicating significant effects on academic climate (Hallinger \& Heck, 1996; Heck, 2000; Heck, Larsen \& Marcoulides, 1990; Hoy \& Hannum, 1997; Printy, 2008; Robinson, Lloyd \& Rowe, 2008; Supovitz, Sirinides \& May, 2009; Tschannen-Moran, 2009). Principals responded to three main sets of questions about their perception of the type and extent of their influence, the evaluation of their position, and the school's relationship with district leaders and decision makers (see Table 2). The first set of items related to the principal's instructional influence. This group of items included how much influence as a principal they have on setting curricular guidelines, establishing policies and practices for grading and student evaluation, establishing policies and priorities for grouping students into classes, and deciding what courses will be offered with responses ranging from "no influence" (0) to "major influence" (2).

The second group of items measured to what extent the principal viewed their position as evaluated on particular academic related and non-academic related tasks. The administrators were asked to rate how much a particular task influenced the evaluation of their position as a principal. Academic related tasks consisted of the performance of school's students on standardized tests and the implementation of new programs or reform efforts such as shared decision making. Non-academic related tasks included to what extent their evaluation was influenced by a good disciplinary environment, efficient administration and relationship with community. The scale for all items about principal evaluation ranged from "no influence" (0) to "major influence" (2).

The final group of items measured the extent to which the principal perceived their school's relationship with central office and the school boards as cooperative. The survey asked the principal to consider how to characterize the school's relationship with school board or governing board and the school's relationship with central office administrators. The responses for these two items ranged from "very cooperative" (0) to "not cooperative" (3).

\section{School level covariates}

The set of school level control variables were selected based on their significant effect on academic climate (Plank, Bradshaw \& Young, 2009; Raudenbush, Rowan \& Kang, 1991; Shouse, 1997). The urbanicity of the school was utilized as a categorical variable with suburban as a reference group (Raudenbush, Rowan \& Kang, 1991). School size was also split into categories, small, medium, large and extra large, with medium as a reference group (Leithwood \& Jantzi, 2009). The percent of students receiving 
Table 1. Descriptive statistics and ELS:2002 variables for subsample of public schools after multiple imputation with listwise deletion

\begin{tabular}{|c|c|c|c|c|c|}
\hline Variable & Mean & $S D$ & Min & $\operatorname{Max}$ & $\begin{array}{l}\text { Description } \\
\text { (ELS:2002 variable) }\end{array}$ \\
\hline Academic climate & 2.788 & 0.679 & 0.2 & 4 & BYA51A-E, $\alpha=0.850$ \\
\hline \multicolumn{6}{|l|}{ School variables: } \\
\hline Urban & 0.260 & 0.439 & 0 & 1 & BYURBAN=1 \\
\hline Rural & 0.244 & 0.430 & 0 & 1 & BYURBAN=3 \\
\hline Small enrollment & 0.191 & 0.394 & 0 & 1 & BYSCENP, 1-599 students \\
\hline Large enrollment & 0.308 & 0.462 & 0 & 1 & BYSCENP, 1200-1999 students \\
\hline Extra Large enrollment & 0.212 & 0.409 & 0 & 1 & BYSCENP, 2000-2500+ students \\
\hline$\%$ Free Lunch (Grade 10, SES) & -0.279 & 1.003 & -1.506 & 1.788 & BY10FLP, $z$-score \\
\hline Social disorder & 0.203 & 0.337 & -1.61 & 1.25 & $\begin{array}{l}\text { BYA49D-J,N,O,Q, } \\
\text { reverse coded, natural log, } \\
\alpha=0.841\end{array}$ \\
\hline Instructional influence & 1.421 & 0.388 & 0.2 & 2 & BYA46B-F, $\alpha=0.762$ \\
\hline \multicolumn{6}{|l|}{ Principal evaluated on (non-academic tasks): } \\
\hline Disciplinary environment & 0.909 & 0.288 & 0 & 1 & BYA48B, $1,2=0 ; 3=1$ \\
\hline Efficient administration & 0.907 & 0.291 & 0 & 1 & BYA $48 C, 1,2=0 ; 3=1$ \\
\hline Relationship with community & 0.683 & 0.466 & 0 & 1 & BYA48E, $1,2=0 ; 3=1$ \\
\hline \multicolumn{6}{|l|}{ Principal evaluated on (academic tasks): } \\
\hline Test scores & 0.663 & 0.473 & 0 & 1 & BYA48A, $1,2=0 ; 3=1$ \\
\hline New programs/reform & 0.592 & 0.492 & 0 & 1 & BYA48F, $1,2=0 ; 3=1$ \\
\hline $\begin{array}{l}\text { School's relationship with school board and } \\
\text { central office }\end{array}$ & 0.888 & 0.315 & 0 & 1 & $\begin{array}{l}\text { BYA47A-B, } 1,2=1 ; 3,4=0, \\
\alpha=0.777\end{array}$ \\
\hline Total Sample & 439 & & & & \\
\hline
\end{tabular}

free lunch in grade 10 was used as a proxy for socioeconomic status and $\mathrm{z}$-scored such that 0 represented the average number of grade 10 students who received free lunch at school.

In addition to the above standard covariates, the frequency of student social disorder reported by the principal was included in our analysis due to its relationship with academic climate and socioeconomic status (Battistich, Solomon, Kim, Watson \& Schaps, 1995; Brand, Felner, Shim, Seitsinger \& Dumas, 2003). ELS:2002 provided several measures of social disorder in the high schools from absenteeism to gang activity (see Table 2). This included physical conflict is a problem, robbery/theft is a problem, vandalism is a problem, use of alcohol is a problem, use of illegal drugs is a problem, students on drugs/alcohol is a problem, sale of drugs near school is a problem, student bullying is a problem, verbal abuse of teachers is a problem, student disrespect for teachers is a problem. Principals responded with a frequency for the type of misbehavior on a scale from "happens daily" (0) to "never happens" (4).

\section{Analysis}

The data analyses included factor and reliability analysis prior to a forward stepwise multiple linear regression. Before analysis, all variables were examined for linearity, normality, collinearity and homoscedasticity. For the single factor principal leadership variables about how the principal perceived their evaluation of academic and non-academic tasks, due to high level of skewness that could not be corrected with a simple transformation, these measures were recoded no influence to minor influence on evaluation into 0 , and major influence on evaluation into 1 . The relationship with school board and central office composite, also with a high level of skewness that could not be corrected with a simple transformation, was recoded from Not cooperative and Somewhat cooperative to 0 and Cooperative and Very cooperative to 1 . However, the social disorder composite was transformed using a natural $\log$ in order to better fit a normal curve.

In order to reduce the number of variables and prevent issues of multicollinearity, items that measured a similar construct were analyzed with exploratory factor analysis to form a composite (Mertler \& Vannatta, 2002). Table 2 presents the four composites, or item aggregates, that were created from separate factor analysis results: academic climate, social disorder, instructional influence, and relationship with school board/central office. All composite items for each of the analyses loaded onto single factors, each with a relationship over .5 (see Table 2). Cronbach's alpha was 
Table 2. Factor loadings and Chronbach's alpha for composite variables

\begin{tabular}{llr}
\hline Factor and items label & Item description & Item loading \\
\hline Academic Climate & & .766 \\
$\alpha=.850$ & Student morale is high & .845 \\
& Teachers press students to achieve & .772 \\
& Teacher morale is high & .828 \\
& Learning is high priority for students & .749 \\
& Students expected to do homework & .571 \\
Social Disorder & & .654 \\
$\alpha=.841$ & How often physical conflicts a problem & .591 \\
& How often robbery/theft a problem & .725 \\
& How often vandalism a problem & .777 \\
& How often use of alcohol a problem & .762 \\
& How often use of illegal drugs a problem & .737 \\
& How often students on drugs/alcohol a problem & .546 \\
& How often sale of drugs near school a problem & .543 \\
& How often student bullying a problem & .521 \\
Instructional Influence & How often verbal abuse of teachers a problem & \\
$\alpha=.762$ & How often disrespect for teachers a problem & .651 \\
& & .701 \\
& Principal's influence on grouping students & .742 \\
& Principal's influence on course offerings & .755 \\
& Principal's influence on instructional materials & .680 \\
Relationship with school board and & Principal's influence on curricular guidelines \\
central office & Principal's influence on grading and evaluation & \\
&
\end{tabular}

calculated for each composite scale, with all composites exceeding an alpha of 0.7 .

\section{Analytic Model}

To appropriately estimate the independent influence of school leadership on academic climate, multiple regression was used to control for covariates (Howell, 2008; Mertler \& Vannatta, 2002). Multiple regression models the influence of the independent variables on the dependent variable while holding all other variables constant. In addition, multiple regression provides the total explained variance for each factor on the dependent variable (Howell, 2008; Mertler \& Vannatta, 2002). Thus, multiple regression tests for the extent to which a variable predicts the outcome and the amount of variance explained by the independent variables and covariates on the dependent variable. We tested the following equation using SPSS/PASW v18 software with a forward stepwise multiple linear regression:

$\hat{Y}($ academic climate $)=\beta_{0}+[\beta($ urban $)+\beta($ rural $)+\beta$
$($ small $)+\beta($ large $)+\beta($ extra large $)+\beta($ free lunch $)+$
$\beta($ social disorder $)]+[\beta($ instructional influence $)]+[$
$\beta($ disciplinary environment $)+\beta($ efficient administration $)$
$+\beta($ community $)]+[\beta$ (test scores $)+\beta($ new programs $)+$
$\beta($ central office $)]$

This equation was entered into the analysis in blocks using forward stepwise regression. Stepwise regression helps to identify the change in the contributions of particular variables toward the explanation of the dependent variable as more variables are added into the regression. In addition, this process demonstrates the stability of factors in relation to one another. School characteristics were entered first, followed by social disorder, instructional influence, non-academic related factors of principal evaluation, academic related factors of principal evaluation, and finally, school's relationship with school board and central office, which are noted by the brackets in the equation.

\section{RESULTS}

The purpose of this study is to examine the independent effects of high school principal's perceptions of their leadership on academic climate, controlling for multiple school-level variables. We analyzed the ELS:2002 base year administrator survey of $n=439$ U.S. high school principals from 2002 using forward stepwise multiple linear regression. The results of each of the four models analyzed are presented in Table 3.

The results of the forward stepwise regression indicated that each of the four models were significantly different from the previous step and as indicated in Table 3, each block of variables entered in each successive model explained more of the variance in principal perception of academic climate. In Model 1, we first examined the independent effects of multiple school-level variables on the principal's perception of academic climate. School locale, as well as enrollment was not significant in the 
Table 3. Multiple linear regression estimating the independent effects on principal perception of academic climate as the dependent variable.

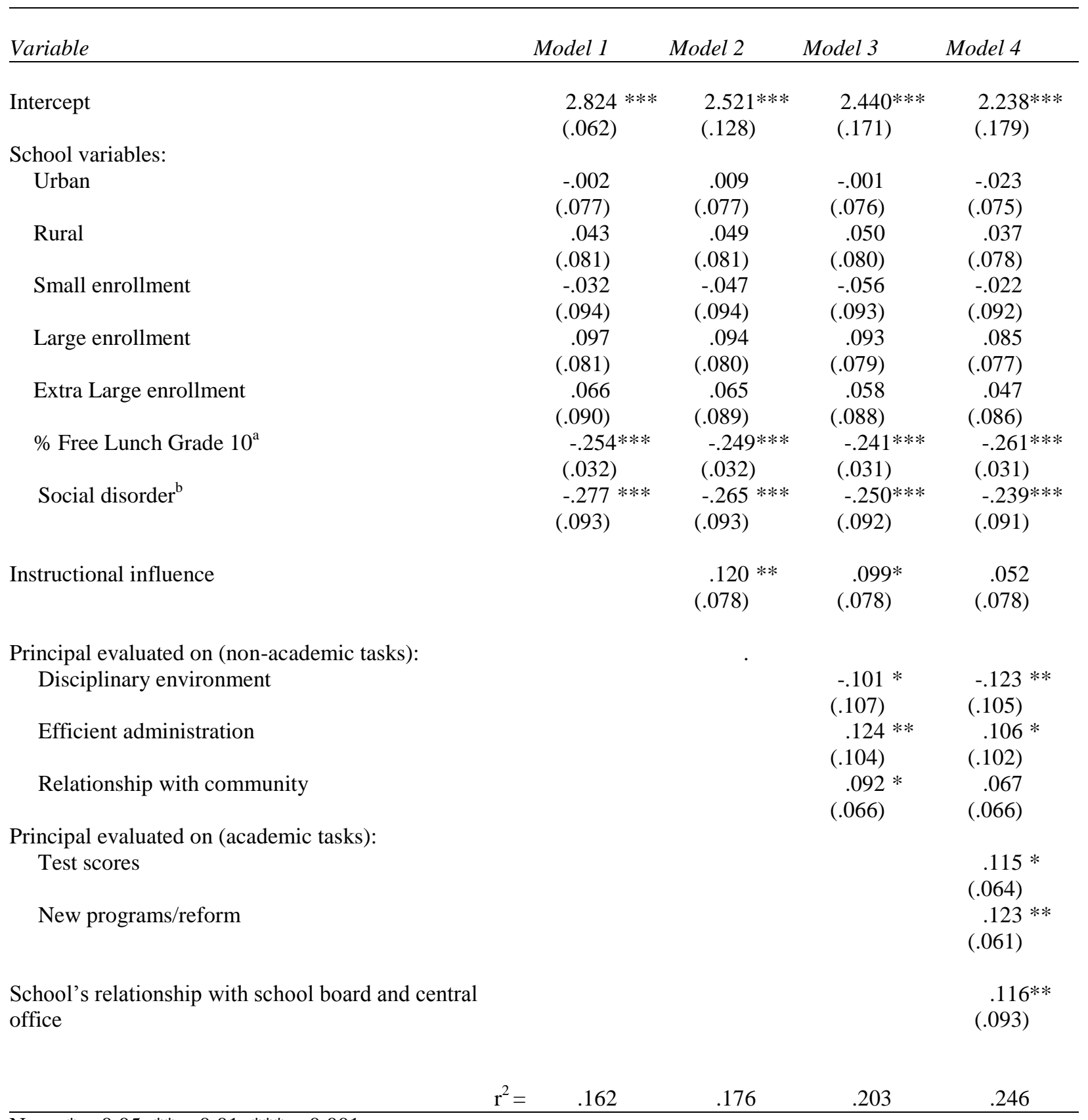

Note: $* \mathrm{p}<0.05, * * \mathrm{p}<0.01, * * * \mathrm{p}<0.001$

Note: All coefficients are standardized betas, and can be interpreted as effect sizes

${ }^{\mathrm{b}}=z$-score, ${ }^{\mathrm{b}}=$ Natural Log 
model, while percentage free lunch students in grade 10 and the composite social disorder variable were both negative and significant. Model 1 explained 16.2 percent of the variance in academic climate. This finding that school urbanicity and size do not significantly impact a principal's perception of the academic climate of the school replicates and extends much of the past work on academic climate (Anderson, 1982; Goddard, Sweetland, \& Hoy, 2000; Griffith, 1999; Heck, 2006; Hoy \& Hannum, 1997; Hoy, Tarter, \& Bliss, 1990; Hoy, Tarter \& Woolfolk Hoy, 2006; Phillips, 1997; Rice, 2001; Shouse, 1996; Wilkins \& Kuperminc, 2010), extending this finding to a large national U.S. sample of principals and schools. The significant negative effects of the percentage of free lunch students in the school replicates much of the past literature (Garmezy, 1991; Gottredson, Gottredson, Payne \& Gottredson, 2005; Raudenbush, Rowan \& Kang, 1991; Seashore Louis et al., 2010; Welsh, 2000; Wilson, 2004) that has also indicated that principals have a more negative view of academic climate in schools with more economically disadvantaged student populations.

In Model 2, we added the composite for the principal's perception of their influence over instruction. Instructional influence was positive and significant in the model, and explained an additional 1.4 percent of the variance in academic climate. Model 3 added the principal's perception of how they were evaluated on nonacademic tasks. Each of the variables were significant in the model, and the model explained 20.3 percent of the variance in principal perception of academic climate, an increase of 2.7 percent over Model 2. Interestingly, Model 3 indicates that principals who felt that they were evaluated more on the disciplinary environment of their schools had a more negative view of the academic climate of their schools, controlling for the other variables in the model, while evaluation on efficient administration and the principal's relationship with the community were both significant and positive.

Model 4, as our final model, included the addition of the principal's perception of the extent that they were evaluated on academic tasks, such as test scores and new programs or reforms, as well as the school's relationship with the school board and the central district office. Model 4 explained a quarter of the variance in the principal's perception of the academic climate (24.6\%), an increase of 4.3 percent over Model 3. The principal's perception of the extent that they were evaluated on test scores and new programs or reforms were both positive and significant in the model, as was their perception of the school's relationship with the school board and central office, controlling for the other variables in the model. Of note is that when these three variables were added to the model, instructional influence and the school's relationship with the community became non-significant. Given the past literature reviewed above, this was an unexpected and intriguing finding. This indicates that in Model 4, not only does the model explain more of the variance than Model 3, as indicated by the increase in the $\mathrm{R}^{2}$, but that the three additional variables are accounting for the variance in the principal's perception of the academic climate of the school previously attributed to instructional influence and the school's relationship with the community. To further explore this finding, we reanalyzed the data, adding each of the three additional variables in Model 4 as individual blocks, principal evaluated on test scores, new programs/reforms, and the school's relationship with the school board and central office. This analysis showed that each of the three additional variables accounted for about equal amounts of the variance previously attributed to both instructional influence and relationship with community (data not shown).

Additionally, since the coefficients are expressed as standardized beta coefficients, the magnitude of each coefficient can be interpreted as its relative contribution to the model. In Model 4, the size of the coefficients for percent free lunch students and the social disorder composite both exceeded the magnitude of the other significant variables in the model, indicating that these two indicators of socio-economic status of the students in the school and the level of problematic student behavior in the school are very important when it comes to the principal's perception of the academic climate. This is also indicated by the initial $\mathrm{R}^{2}$ of Model 1 that indicated that these variables help to explain about one sixth of the variance in principal perception of academic climate.

We turn next to discussing each of these findings as they relate to the previous literature on principal's perception of the academic climate in their schools.

\section{DISCUSSION}

To date, the current literature has indicated that the principal's perception of the academic climate of the school is a historically under-researched area, yet important to address since the principal has an integral role in setting and maintaining the academic climate of a school. Past research has focused on the mediated effect of the academic climate of the school on student performance, but information on the associated influence of school and principal-level variables on how principals perceive the academic climate is scarce. Knowing more about what influences and is associated with principal perception of academic climate can help inform current models of school leadership, extending the mediated model theory discussed above to the principal and the question of what are the most significant factors associated with a principal's perception of academic climate. This study is a novel and significant contribution to this domain in three main ways. First, this study is one of the first to examine a large nationally representative dataset of U.S. high school principal perceptions of academic climate. Second, we found that student SES and the social disorder of the school were negatively related to the principal's perception of the academic climate in their school, confirming and extending the past research. Third, our analysis suggests that when controlling for the other variables in the model, the associated effect of the principal's perception of their influence over instruction on academic climate and the school's relationship with the community is attenuated by the extent to which the principal perceived that they were evaluated on test scores, new programs or reforms and their relationship with the school district.

This study focused exclusively on the principal's perception of academic climate. Thus, our measure of academic climate is the principal's perception of the academic climate. Few studies have considered the independent effects on the principal's perception of academic climate, and instead usually survey teachers to create a "school-wide" academic climate variable. However, as noted by Leithwood and Jantzi (2008), a focus on the principal alone is needed to help understand what influences their perceptions of the academic climate to help inform future theory and practice. As noted in much of the literature (Firestone \& Wilson, 1985; Heck, 2000; Leithwood \& Jantzi, 1999; Leithwood, Mascall, Strauss, Sacks, Memon \& Yashkina, 2007; Printy, 2008; Raudenbush, Rowan \& Kang, 1991; Tschannen-Moran, 2009), the principal is one of the main drivers of a school's academic 
climate. Thus, their perception and the significant influences on that perception are important to study, given that we know little about what influences that perception.

We found that when controlling for other variables in the model, as principal perception of being evaluated on discipline increased, their perception of the academic climate decreased, while both percent free lunch students and the social disorder of the school were both also negative and significant in the models. This is important because these appear to be independent effects on the perception of the academic climate. Our results suggest that for this national sample of high school principals, they appear to be predisposed to a more negative view of the academic climate when these other variables are elevated. This places schools with low SES and discipline issues even further behind, maybe creating a feedback loop that is a self-fulfilling prophecy, that "challenging" schools will have a more "challenging" academic climate. One logical step to deal with such a challenge, such as problems with social disorder, would be to highlight the role of the principal as a disciplinarian with encouragement from the district through principal evaluations of a good disciplinary environment. One of the main components of the long line of school effectiveness research (Anderson, 1982; Brand, Felner, Shim, Seitsinger \& Dumas, 2003; Cusick, 1983; Edmonds, 1979; Goh, Young \& Fraser, 1995; Griffith, 1999; Griffith, 1995; Heck, 2006; Rumberger \& Palardy, 2005) indicates that "peace in the halls", is a precondition of school improvement and one of the four to five factors that are consistently noted in effective schools versus less effective schools. However, our data indicates that a focus on discipline, to the extent that a principal feels that she or he is evaluated on discipline, may have a non-intuitive inverse relationship with the principal's perception of the academic climate, independent of the school SES and the social disorder issues. A less extensive better measure of this orderly, safe environment in combination with managerial duties discussed in the literature (Heck, 2006; Robinson, Lloyd \& Rowe, 2008) might have been explained by the significant and positive relationship of the principal's evaluation on efficient administration. Although good discipline may be an initial cornerstone in creating quality schools and climate, these findings suggest that in order to increase the leader's perception of the academic climate, district evaluation of the school leadership position should primarily support principal goals for academicrelated tasks.

Principal perceptions of their degree of influence on instruction through grouping of students, course offerings, instructional materials, curriculum guidelines and grading policies was significant controlling for SES, social disorder and the evaluation of managerial, or non-academic tasks. However, once measures of the principal's perception of the extent to which they were evaluated on test scores, new programs or reforms as well as the school's relationship with the district, were added into the model, these district evaluations of principal progress toward increased achievement accounted for the significance of the principal's influence on instructional processes. Examined as a district effect, these three variables can be taken as an assessment of the district's influence over the school by the principal. Thus, the perceived district control of the evaluation of a school's academic improvements explained the variance attributed to the day to day instructional influence of the principal. This novel finding is supported by literature that has suggested that changes in the instructional influence of leaders should be supported at the district level in order to be successful (Bowers, 2008; Firestone \&
Martinez, 2007; Leithwood, 2010; Mangin, 2007), and further, when emphasized through principal evaluations, support an increase in the principal's perception of the school's academic climate. Perhaps it is the affirmation and direction received from these district evaluations that influences the self-efficacy and collective-efficacy of principals. This may reflect the findings of Leithwood and Jantzi (2008) and Heck and Hallinger (2006) that efficacy indirectly influences student achievement or growth through school conditions. The present study extends this literature related to the influence of principal leadership on student learning in two main ways. First, this study extents prior literature by concluding that the principal's perception of district evaluations based on implementation of programs and student performance might explain the variance regularly attributed to principal influence on instructional processes (Heck, Larsen \& Marcoulides, 1990; Supovitz, Sirinides \& May, 2010). As an extension of this previous work, our findings would suggest that surveys designed and implemented to evaluate the learningcentered leadership of principals (Goldring, Porter, Murphy, Elliott \& Craven, 2009) might be more accurate measures of the contribution of principal leadership to the school conditions that contribute to student outcomes compared to measures of the extent and frequency of a principal's influence on instructional tasks. Second, this study supports the theory postulated by Leithwood and Jantzi (2008) by confirming a relationship between district conditions as perceived by the principal and principal perception of academic climate. This possibly adds the principal perception of the academic climate to previously used measures of efficacy that drive principals to create school conditions which link to student achievement. These combined measures of academic climate perceptions and efficacy possibly have a larger latent construct driving principal decisions about school conditions, much like the overall construct of academic optimism, consisting of efficacy, academic climate and faculty trust, tested with teachers as the unit of analysis (Hoy, Tarter \& Woolfolk Hoy, 2006).

In addition, the strong relationship between evaluation of principal academic related tasks and academic climate explained the variance between the evaluation of the principal on the relationship with the community and their view of academic climate. The literature has shown that the school context, including community type, school size and socioeconomic status, has defined how a principal leads a school (Hallinger \& Heck, 1996; Plank, Bradshaw \& Young, 2009; Raudenbush, Rowan \& Kang, 1991; Shouse, 1997). The district's evaluation of managing this relationship between principal and the larger community was significant until the evaluation on test scores and new programs were added into the model. In prior studies, the relationship with the community has been included into models of overall academic climate, a piece of a larger construct (Hallinger \& Heck, 1996; Hoy, Tarter \& Woolfolk Hoy, 2006). Our findings suggest that it is important to include in models of academic climate; however, it does not independently influence academic climate when controlling for the academic standards on which principals are evaluated.

Finally, we found a strong positive effect of the school's relationship with the district on the principal's perception of the academic climate, all other variables being equal. This expands the prior discussion about the importance of district evaluation of principals on academic goals (see Cohen, Raudenbush and Ball,2003). Not only should districts emphasize standards around school performance and implementation of programs/reforms, but 
the cooperative relationship created between the school and the district further increases the principal's positive view of the academic climate. The cooperation between the school and district toward these academic goals serves to benefit the academic climate through both the evaluation process and the support provided for increased school performance and implementation of programs. A substantive amount of literature has confirmed the importance of the relationship between school and district officials (Firestone \& Martinez, 2007; Leithwood, 2010, Leithwood \& Jantzi, 2008; Mangin, 2007).

\section{Limitations}

The current study had several limitations. First, the sample used in this study was limited only to public high schools in 2002. Generalizations cannot be made to all principals of schools at each grade levels. Second, the scope of this study was purposely limited to principal perceptions. Since little is known about principal perceptions of academic climate, the results of this study do not necessary extend to effects on student achievement because the relationship between measures of academic climate at separate levels of analysis, students, teachers and principals is not yet known. Third, principal background characteristics, such as training and experience, although sometimes not found significant in the literature, were not controlled for since they did not exist within the data. Fourth, our measure of instructional influence is not a representation of instructional leadership since it does not measure the instructional interactions between teacher and principal, such as monitoring.

\section{Conclusions}

This study is one of the few to study a large sample of U.S. principals from across the U.S. Our results help describe the factors most associated with principal's perception of academic climate. This helps further theory about the link between academic climate, efficacy, leadership, and student achievement. As we have detailed the factors associated with principal perception, we encourage future studies to explore the factors most associated with teacher perception of academic climate, and how harmony or dissonance between these two sets of perceptions impacts the academic climate of a school, and then how that impact is mediated through to student achievement. The future examination of the relationship between principal's perception of academic climate and efficacy serves as a link to assessing its value as an additional mediating factor between district and school conditions. Future work should also focus on confirming our results beyond principal perception. We admit that our focus is quite limited. It may be that the principal's perception of social disorder, their influence over school decisions, and if they are evaluated on discipline, is quite different than the perception from the view of the district, teachers, students and parents. Future work should explore these topics from these multiple perspectives examining surveys of schools as well as incorporating these issues into qualitative studies that may shed more light on the issues through interviews and observations.

Based on the findings in this study, we recommend that district leaders closely assess the ways in which principals are evaluated. Further, the district and school board should find ways in which to support their relationship with the principal in order to create a stronger academic climate within the school. Principals should be aware of how the confines of their position relate to their views of teachers and students. Principals should also focus on building better relationships with the district office in order to negotiate the needs of the school to support the academic climate. From a policy standpoint, this study confirms the importance placed on the ways in which principals are evaluated. Researchers should conduct further work to investigate the effects of particular principal evaluation factors on the change in academic climate and principal perceptions about their students and staff.

\section{Recommended Citation:}

Urick, A., \& Bowers, A. J. (2011). What Influences Principals' Perceptions of Academic Climate? A Nationally Represenative Study of the Direct Effects of Perception on Climate. Leadership and Policy in Schools, 10(3), 322-348. doi:

$\underline{10.1080 / 15700763.2011 .577925}$

\section{References}

Anderson, C. (1982). The search for school climate: A review of the research. Review of Educational Research, 52(3), $368-420$.

Battistich, V., Solomon, D., Kim, D., Watson, M., \& Schaps, E. (1995). Schools as communities, poverty levels of student populations, and students' attitudes, motives, and performance: A multilevel analysis. American Educational Research Journal, 32(3), 627-658.

Bowers, A. (2008). Promoting excellence: Good to great, NYC's district 2, and the case of a high-performing school district. Leadership and Policy in Schools, 7(2), 154177.

Brand, S., Felner, R., Seitsinger, A., Burns, A., \& Bolton, N. (2008). A large scale study of the assessment of the social environment of middle and secondary schools: The validity and utility of teachers' ratings of school climate, cultural pluralism, and safety problems for understanding school effects and school improvement. Journal of School Psychology, 46, 507-535.

Brand, S., Felner, R., Shim, M., Seitsinger, A., \& Dumas, T. (2003). Middle school improvement and reform: Development and validation of a school-level assessment of climate, cultural pluralism, and school safety. Journal of Educational Psychology, 95(3), 570588.

Cantillon, D. (2006). Community social organization, parents, and peers as mediators of perceived neighborhood block characteristics on delinquent and prosocial activities. American Journal of Community Psychology, 37(1/2), 111-127.

Cohen, D. K., Raudenbush, S., \& Ball, D. L. (2003). Resources, instruction and research. Educational Evaluation and Policy Analysis, 25(2), 119-142.

Cusick, P. A. (1983). The egalitarian ideal and the American high school: Studies of the schools. New York: Longman.

Daly, A. (2009). Rigid response in an age of accountability: The potential of leadership and trust. Educational Administration Quarterly, 45(2), 168-216.

Danielsen, A., Wiium, N., Wilhelmsen, B., \& Wold, B. (2010). Perceived support provided by teachers and classmates and students' self-reported academic initiative. Journal of School Psychology, 48, 247-267.

Edmonds R. (1979). Effective schools for urban poor. Educational Leadership, 37, 15-24.

Enders, C. (2008). Analysis of missing data. AERA professional development course, March 25, 2008. 
Firestone, W., \& Martinez, C. (2007). Districts, teacher leaders, and distributed leadership: Changing instructional practice. Leadership and Policy in Schools, 6, 3-35.

Firestone, W. \& Wilson, B. (1985). Using bureaucratic and cultural linkages to improve instruction: The principal's contribution. Educational Administration Quarterly, 21(2), 7-30.

Garmezy, N. (1991). Resiliency and vulnerability to adverse development outcomes associated with poverty. American Behavioral Scientist, 34, 416-430.

Goh, S., Young, D., \& Fraser, B. (1995). Psychosocial climate and student outcomes in elementary mathematics classrooms: A multilevel analysis. The Journal of Experimental Education, 64(1), 29-40.

Goldring, E., Huff, J., May, H., \& Camburn, E. (2007). School context and individual characteristics: What influences principal practice? Journal of Educational Administration, 46(3), 332-350.

Goldring, E., Porter, A., Murphy, J., Elliot, S., \& Cravens, X. (2009). Assessing learning-centered leadership: Connections to research, professional standards, and current practices. Leadership and Policy in Schools, 8, 1-36.

Gottfredson, G., Gottfredson, D., Payne, A, \& Gottfredson, N. (2005). School climate predictors of school disorder: Results from a national study of delinquency prevention. Journal of Research in Crime and Delinquency, 42, 412-444.

Griffith, J. (1999). School climate as social order and social action: A multi-level analysis of public elementary school student perceptions. Social Psychology of Education. 2, 339-369.

Griffith, J. (1999a). The school leadership/school climate relation: Identification of school configurations associated with change in principals. Educational Administration Quarterly, 35(2), 267-291.

Griffith, J. (1995). An empirical examination of a model of social climate in elementary school. Basic and Applied Social Psychology, 17(1-2), 97-117.

Goddard, R., Sweetland, S., \& Hoy, W. (2000). Academic emphasis of urban elementary schools and student achievement in reading and mathematics: A multilevel analysis. Educational Administration Quarterly, 36(5), 683-702.

Hallinger, P. \& Heck, R. (1996). Reassessing the principal's role in school effectiveness: A review of empirical research, 1980-1995. Educational Administration Quarterly, $32(1), 5-44$

Heck, R. (2006). Assessing school achievement progress: Comparing alternative approaches. Educational Administration Quarterly, 42(5), 667-699.

Heck, R. (2000). Examining the impact of school quality on school outcomes and improvement: A value-added approach. Educational Administration Quarterly, 36(4), 513-552.

Heck, R. \& Hallinger, P. (2009). Assessing the contribution of distributed leadership to school improvement and growth in math achievement. American Educational Research Journal, 46, 659-689.

Heck, R. Larsen, T., \& Marcoulides, G. (1990). Instructional leadership and school achievement: Validation of a causal model. Educational Administration Quarterly, 26(2), 94-125.
Heck, R. \& Marcoulides, G. (1996). School culture and performance: Testing the invariance of an organizational model. School Effectiveness and School Improvement, 7(1), 76-95.

Hoy, W. \& Hannum, J. (1997). Middle school climate: An empirical assessment of organizational health and student achievement. Educational Administration Quarterly, 33(3), 290-311.

Hoy, W., Sweetland, S., \& Smith, P. (2002). Toward an organizational model of achievement in high schools: The significance of collective efficacy. Educational Administration Quarterly, 38(1), 77-93.

Hoy, W., Tarter, C. J., \& Bliss, J. (1990). Organizational climate, school health, and effectiveness: A comparative analysis. Educational Administration Quarterly, 26, 260-279.

Hoy, W., Tarter, C.J., \& Woolfolk Hoy, A. (2006). Academic optimism of schools: A force for student achievement. American Educational Research Journal, 43(3), 425446.

Ingles, S. J., Pratt, D., Rogers, J., Siegel, P., Stutts, E., \& Owings, J. (2004). Education longitudinal study of 2002: Base year data file user's manual. Washington, D.C.: National Center for Education Statistics, Institute of Education Sciences, U.S. Department of Education.

Ingles, S. J., Pratt, D., Wilson, D., Burns, L., Currivan, D., Rogers, J., \& Hubbard-Bednasz, S. (2007). Education longitudinal study of 2002: Base-year to second followup data file documentation. Washington, DC: National Center for Education Statistics, Institute of Education Sciences, U.S. Department of Education.

Leithwood, K. (2010). Characteristics of school districts that are exceptionally effective in closing the achievement gap. Leadership and Policy in Schools, 9, 245-291.

Leithwood, K., \& Jantzi, D. (2009). A review of empirical evidence about school size effects: A policy perspective. Review of Educational Research 79 (1):464-490.

Leithwood, K. \& Jantzi, D. (2008). Linking leadership to student learning: The contributions of leader efficacy. Educational Administration Quarterly, 44, 496-528.

Leithwood, K. \& Mascall, B. (2008). Collective leadership effects on student achievement. Educational Administration Quarterly, 44, 529-561.

Leithwood, K., Seashore Louis, K., Anderson, S., \& Wahlstrom, K. (2004). How leadership influences student learning. Research report to the Wallace foundation.

MacNeil, A., Prater, \& Busch, S. (2009). The effects of school culture and climate on student achievement. International Journal of Leadership in Education, 12(1), 73-84.

Mangin, M. (2007). Facilitating elementary principals' support for instructional teacher leadership. Educational Administration Quarterly, 43, 319-357.

McEvoy, A. \& Welker, R. (2000). Antisocial behavior, academic failure and school climate: A critical review. Journal of Emotional and Behavioral Disorders, 8(3), 130-140.

McKown, C., \& Weinstein, R. (2008). Teacher expectations, classroom context, and the achievement gap. Journal of School Psychology, 46, 235-261.

Meece, J., Anderman, E., \& Anderman, L. (2006). Classroom goal structure, student motivation, and academic achievement. Annual Review of Psychology, 57, 487503. 
Mertler, C. \& Vannatta, R. (2002). Advanced and multivariate statistical methods. Glendale, CA: Pyrczak Publishing.

Mortimore, P. (1993). School effectiveness and the management of effective learning and teaching. School Effectiveness and School Improvement. 4(4), 290-310.

Murphy, J., Elliott, S., Goldring, E. \& Porter, A. (2007). Leadership for learning: A research-based model and taxonomy of behaviors. School Leadership and Management, 27(2), 179-201.

Oakes, J. (1989). What educational indicators? The case for assessing the school context. Educational Evaluation and Policy Analysis, 11(2), 181-199.

Phillips, M. (1997). What makes schools effective? A comparison of the relationship of communitarian climate and academic climate to mathematics achievement and attendance during middle school. American Educational Research Journal, 34(4), 633-662.

Plank, S., Bradshaw, C., \& Young, H. (2009). An application of the broken-window and related theories to the study of disorder, fear and collective efficacy in schools. American Journal of Education, 115, 227-247.

Planty, Mike, Jill F. DeVoe, Jeffrey A. Owings, and Kathryn Chandler. 2006. An examination of the conditions of school facilities attended by 10th-grade students in 2002. Washington, DC: U.S. Department of Education, National Center for Education Statistics.

Printy, S. (2008). Leadership for teacher learning: A community of practice perspective. Educational Administration Quarterly, 44(2), 187-226.

Raudenbush, S., Rowan, B., \& Kang, S. (1991). A multilevel, multivariate model for studying school climate with estimation via the EM algorithm and application to US high school data. Journal of Educational Statistics, 16(4), 295-330.

Rice, J. (2001). Explaining the negative impact of the transition from middle to high school on student performance in mathematics and science. Educational Administration Quarterly, 37(3), 372-400.

Rizzuto, T., LeDoux, J., \& Hatala, J. (2009). It's not just what you know, it's who you know: Testing a model of the relative importance of social networks to academic performance. Social Psychology Education, 12, 175189.

Robinson, V., Lloyd, C., \& Rowe, K. (2008). The impact of leadership on student outcomes: An analysis of the differential effects of leadership types. Educational Administration Quarterly, 44, 635-674.

Seashore Louis, K., Leithwood, K., Wahlstrom, K., Anderson, S., Michlin, M., Mascall, B., Gordon, M., Strauss, T., Thomas, E., \& Moore, S. (2010). Learning from leadership: Investigating the Links to Improved Student Learning. A final research report to the Wallace Foundation.

Shouse, R. (1996). Academic press and sense of community: Conflict, congruence, and implications for student achievement. Social Psychology of Education, 1, 46-68.

Supovitz, J. Sirinides, P., \& May, H. (2010). How principals and peers influence teaching and learning. Educational Administration Quarterly. 46, 31-56.

Tarter, C.J., Sabo, D., \& Hoy, W. (1995). Middle school climate, faculty trust, and effectiveness: A path analysis. Journal of Research and Development in Education, 29(1), 41-49.
Tschannen-Moran, M. (2009). Fostering teacher professionalism in schools: The role of leadership orientation and trust. Educational Administration Quarterly, 45, 217-247.

Welsh, W. (2000). The effects of school climate on school disorder. The ANNALS of the American Academy of Political and Social Science, 567(1), 88-107.

Wilkins, N. \& Kuperminc, G. (2009). Why try? Achievement motivation and perceived academic climate among Latino youth. The Journal of Early Adolescence, 30(2), 246-276.

Wilson, D. (2004). The interface of school climate and school connectedness and relationships with aggression and victimization. The Journal of School Health, 74(7), 293-299.

Urick \& Bowers (2011) 